\title{
Structure and Reactivity of a Biological Soil Crust from a xeric sandy Soil in Central Europe
}

\author{
Michael Hoppert ${ }^{1}$ ), Rudolph Reimer, Anne Kemmling, Annekatrin Schröder, Bettina Günzl*), and \\ Thilo Heinken**)
}

Institut für Mikrobiologie und Genetik, Georg-August-Universität Göttingen, Grisebachstraße 8, 37077 Göttingen, Germany

*) Albrecht-von Haller-Institut für Pflanzenwissenschaften, Vegetationskunde und Populationsbiologie Georg-August-Universität Göttingen, Wilhelm-Weber-Str. 2 Grisebachstraße 8, 37073 Göttingen, Germany **) Institut für Biologie, Systematische Botanik und Pflanzengeographie, Freie Universität Berlin, Altensteinstr. 6, D-14195 Berlin. Present address: Institut für Biochemie und Biologie, Biozönoseforschung/Spezielle Botanik, Universität Postdam, Germany

$\left.{ }^{1}\right)$ corresponding author (email: mhopper@gwdg.de)

\begin{abstract}
The investigation was designed to explore the structure, composition and activity of a biological soil crust on an acidic, sandy soil from a temperate climate. The crust covers several hundreds of square meters on the hilltop of a large terminal moraine. The conjugate alga Zygogonium ericetorum forms the essential matrix for the crust, a dense web of algal filaments with interspersed lichens and mosses. The crust is composed of three layers, with an uppermost layer consisting nearly entirely of a dense algal mat. In lower layers, a parasitic fungus, penetrating the algal cells, is another important component of the crust community. In this soil crust, photosynthetic and respiratory activity is stabilized at low water activities.
\end{abstract}

Key words: Biological soil crust - desiccation tolerance - electron microscopy - Fusarium oxysporum - Zygogonium ericetorum

\section{Introduction}

Soils in temperate climates are regularly covered with communities of vascular plants, accompanied by cryptogams (mosses, sometimes lichens). In arid or semi-arid regions, thin crustose layers dominated by cyanobacteria, lichens and bryophytes frequently cover the surface of various soil types. These sub-aeric biofilms are known as cryptogamic, microbiotic or biological soil crusts. Well-developed crusts often represent over $70 \%$ of the living ground cover and play an important ecological role in deserts or semi-deserts (Belnap et al. 2001).

The crusts increase the stability of soils against erosion, influence water infiltration, and may increase the amount of carbon and nitrogen sources in infertile sandy soils. Biological soil crusts may also successfully compete with higher plants in these areas (Prasse and Bornkamm 2000). Structure, species composition and ecological significance have been described for soil crusts in the SW of the United States, the Negev Desert and Australia (Johansen 1993; Verrecchia et al. 1995; Eldridge and Rosentreter 1999). Frequently, crust organisms are extremophilic or extremotolerant and show adaptations against the deleterious action of periodic wetting and drying (Potts, 1999). In temperate climates of Central Europe, closed crust covers occur only occasionally and are restricted to extreme habitats where they are not outcompeted by higher cryptogams or vascular plants. On xeric grasslands for instance, especially soil lichen communities (accompanied by microalgal flora) are frequent and may be of some ecological significance (e.g. Paus 1997). Crusts dominated by algae have been described as pioneer vegetation on inland dunes (e.g. Pluis 1994) and on sandy soil in young pine plantations (Lukesova 2001).

In Central Brandenburg ("Glauer Berge" area, SW of Berlin), biological soil crusts have been developed in open Scots pine forests on acid sandy soil of a terminal moraine (Heinken 1999). Their overall appearance is similar to soil crusts in arid regions. Closed patches cover up to several tens of square meters and the estimated total size of the crust cover in the area measures several hundreds of square meters. In the following, crust structure and reactivity under stress conditions are presented.

\section{Materials and Methods}

Green algae were cultivated in Ankistrodesmus-medium (Starr 1971), adjusted to pH 3.5 under continuous illumination at $20{ }^{\circ} \mathrm{C}$ and $3000 \mathrm{~lx}$ in a light thermostat. The Fusarium strain was cultivated on 
solid GYM Streptomycete medium (DSMZ medium No. 65, DSMZ 2001) at $25{ }^{\circ}$ C. Pure cultures of Zygogonium were obtained by isolation of a growing filament directly from a re-wetted crust segment re-transferred to a medium plate. After several passages, the algae were grown in pure liquid culture. For comparative analyses, Macrochloris multinucleata (SAG 39.36), Arthronema africanum (SAG 1.89) and Klebsormidium flaccidum (SAG 121.80) were used, all provided by the Culture Collection of Algae (SAG) at the University of Göttingen and grown under conditions as described (Schlösser 1994). Zygogonium cells from pure culture were also inoculated on a bed made of sand grains, which were taken from the sampling area and sterilized prior to use. These plates were grown for three months under light/dark (12:12 h) illumination regime and periodic wetting with sterile tap water.

Measurement of respiratory and photosynthetic activity was performed with homogeneus soil crust samples, exclusively composed of algae and fungal filaments ("algal crust"; no lichens or mosses present) or with preparations from pure cultures. A defined surface area of an algal crust sample $\left(1 \mathrm{~cm}^{2}\right)$ was used for measurement of respiratory activity and oxygen production. Measurements were performed five times, exhibiting a variation within $+/-5 \%$ of the measured activity. Development of $\mathrm{CO}_{2}$ was determined in a gas chromatograph (Shimadzu GC 8 AIT, Shimadzu Corp.), equipped with a thermal conductivity detector and an injector/detector temperature of $105{ }^{\circ} \mathrm{C}$, utilizing a Porapak QS column at a temperature of $75{ }^{\circ} \mathrm{C}$ with helium as carrier gas at a flow rate of $25 \mathrm{ml} / \mathrm{min}$. Oxygen concentration was measured with a Clark-type electrode (Delieu and Walker 1972). Water potentials $\left(a_{w}\right)$ of liquid solutions were adjusted with glycerol and sodium chloride as given by Labuza (1975). Water holding capacity was determined according to Nehring (1960). Extracellular polysaccharides from algal crust samples were purified as described by Gross and Rudolph (1987). Identification of fungal species was performed by the German Collection of Microorganisms and Cell Cultures (Braunschweig, Germany) according to a standard identification scheme.

For transmission electron microscopy, hydrated algal crust samples were embedded in agar (to protect the biofilm), and subjected to dehydration, resin embedding, sectioning and staining according to standard protocols (Venable and Coggeshall 1965, Spurr 1969). At the transmission electron microscope (Philips EM 301), images were taken at calibrated magnifications and an accelerating potential of 80 $\mathrm{kV}$. For scanning electron microscopy, samples from a dry crust were chemically dehydrated in a graded acetone series, critical-point dried and sputter-coated with gold according to a standard preparation procedure (Hoppert and Holzenburg 1998). At the scanning electron microscope (LEO 430), images were captured at an accelerating potential of $15 \mathrm{kV}$. For light microscopy of whole algal crust samples, cells were either embedded in gelatine-glycerol and cut with a steel blade or embedded in Spurr resin, cut with a saw microtome, and mounted on microscope slides (detailed procedures in Hoppert 2003). Samples were optionally stained with an aqueous Ruthenium Red solution (1.5\%, w/v). Fluorescence in situ hybridisation with the eubacterial markers EUB338-Cy3 and non-EUB338Cy3 (Manz et al. 1992) was performed as described (Manz et al. 2000).

\section{Results \\ Features of the Study Site}

The sampling area is a sandy terminal moraine located in Brandenburg, Germany near Trebbin; lat $52^{\circ} 15^{\prime}$, long $13^{\circ} 08^{\prime}-13^{\circ} 11^{\prime}$. The hilltops of the moraine (Weichsel glacial), with a maximum elevation of $93 \mathrm{~m}$, are depleted of organic nutrients by erosion. $\mathrm{The} \mathrm{pH}\left(\mathrm{H}_{2} \mathrm{O}\right)$ of the sandy soil in the uppermost layer measures $3.9-4.1$. The soil is characterized by a rapid permeability and low water capacity. Soil temperature at or near full sunlight in summer will reach approximately $50{ }^{\circ} \mathrm{C}$ (compare BergerLandefeldt, 1964). Thus, at the hilltops at south facing slopes, the upper soil layer desiccates completely after 1-2 d without precipitation in summer periods. Fig. 1a illustrates the plant cover on hilltops. An old grown open lichen pine forest alternates with treeless areas and a pioneer forest with pine and birch (see Heinken 1999 for a detailed description of the forest communities). Higher plants interspersed in these treeless spaces are predominantly small tussock grasses (Corynephorus canescens and Festuca ovina).

The soil surface of the treeless areas is covered with a grayish-brown biological crust layer (up to 0,5 $\mathrm{cm}$ in thickness). Large segments of the crust are exclusively composed of microalgae (algal crust), mainly the conjugate green alga Zygogonium ericetorum (Kützing), accompanied by Ulothrix sp. filaments and Gloeocystis sp. These segments were selected for our studies. Crusts consisting of microalgae have a most homogeneous macroscopic appearance, and large patches may be manually detached easily from the underlying soil. They are as rigid as a piece of cardboard, though more brittle. Other segments of the crust also contain higher cryptogams (see also Heinken 1999), and are therefore 

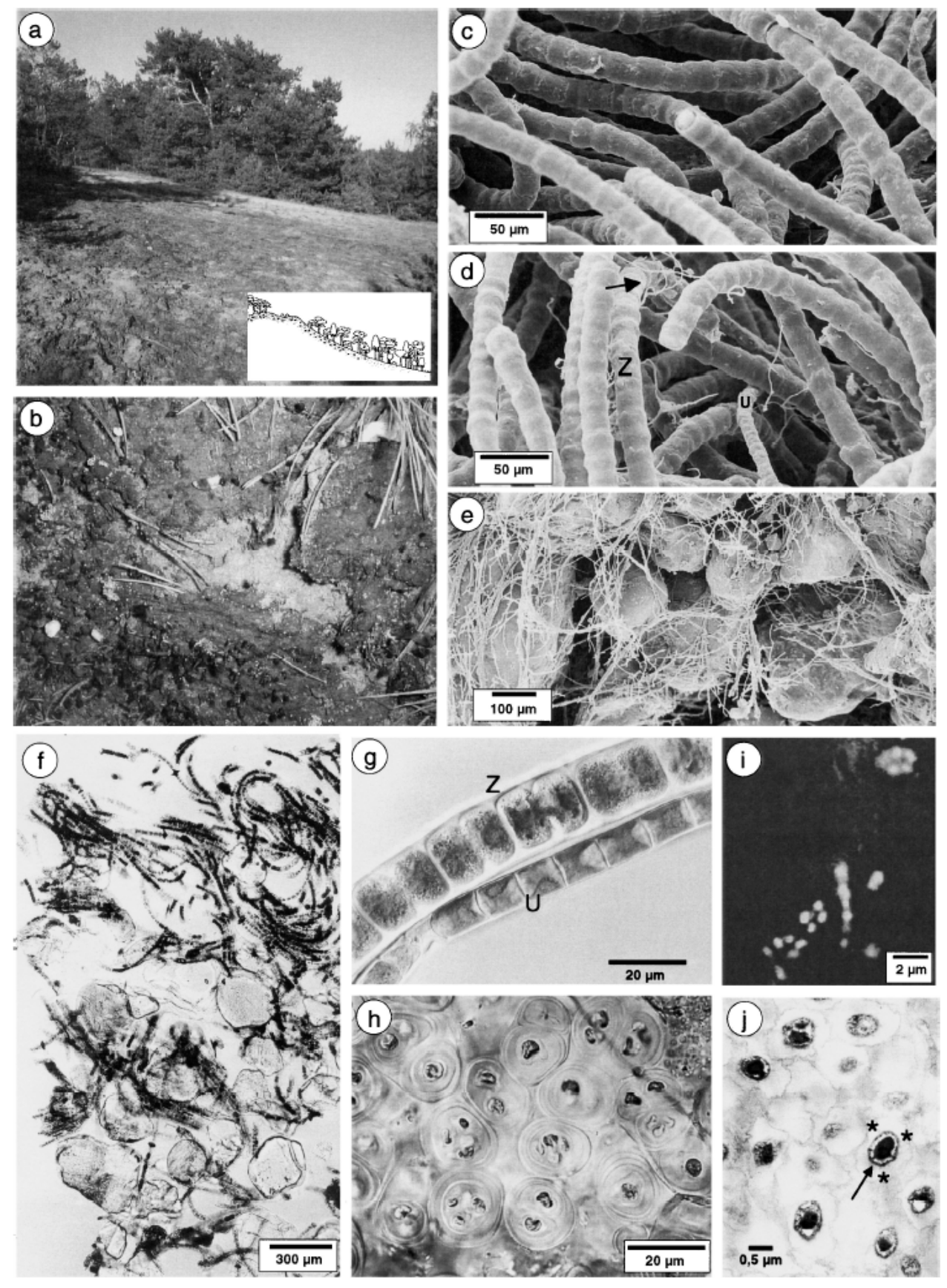

FIGURE 1. Structure and composition of the Zygogonium-dominated soil crust.

a) Open area on the hilltop of the terminal moraine. The soil crust builds up the grayish cover in the fore- and midground of the image. The inset illustrates a transect of the study site; the treeless space in the transect marks the site of the crust cover.

b) Close-up view of the crust cover. In the lower left of the image, a segment of the cover is interspersed with mosses.

c-e) SEM micrographs of crust layers. The uppermost layer (c) is formed by a dense Zygogonium mat; an intermediate layer (d) exhibits Zygogonium (Z) with interspersed thin fungal filaments (arrow). A smaller filamentous alga, presumably Ulothrix sp. is marked with the letter U. A lowest layer (e) exhibits the filaments of the fungus interwoven with sand grains.

f) Longitudinal section of a crust in overview, made with a saw microtome of a resin-embedded sample. In the uppermost layer, the algae form a dense mat. In lower layers, the density of algae decreases and an increasing number of sand grains interwoven in the network are visible. Fungal filaments are not visible in this preparation. g) Zygogonium ericetorum (Z) and Ulothrix sp. (U), grown in an enrichment culture taken from a soil crust sample.

h) Gloeocystis sp. microcolony grown in an enrichment culture taken from a soil crust sample.

$i, j)$ Bacterial microcolonies detected by FISH (i) and electron microscopy (j) in a crust sample rehydrated immediately prior to fixation. In the electron micrograph, extracellular material ( $\mathrm{j}$; asterisks), surrounding each cell (arrow) is visible. 
briefly mentioned here. Besides the algae, the mosses Polytrichum piliferum and Cephaloziella divaricata are eventually interwoven in the crust layer. Especially under canopies of isolated pine and birch trees and around the tussock grasses, the lichens Saccomorpha (Placynthiella) oligotropha, S. icmalea, S. uliginosa, Trapeliopsis granulosa and the mosses Ceratodon purpureus and Pohlia nutans are embedded in the tight network of microalgae (Fig. 1b). Also fruticose lichens, especially Cladonia arbuscula ssp. mitis, C. foliacea, C. phyllophora and C. pyxidata, are here grounded in the crust cover.
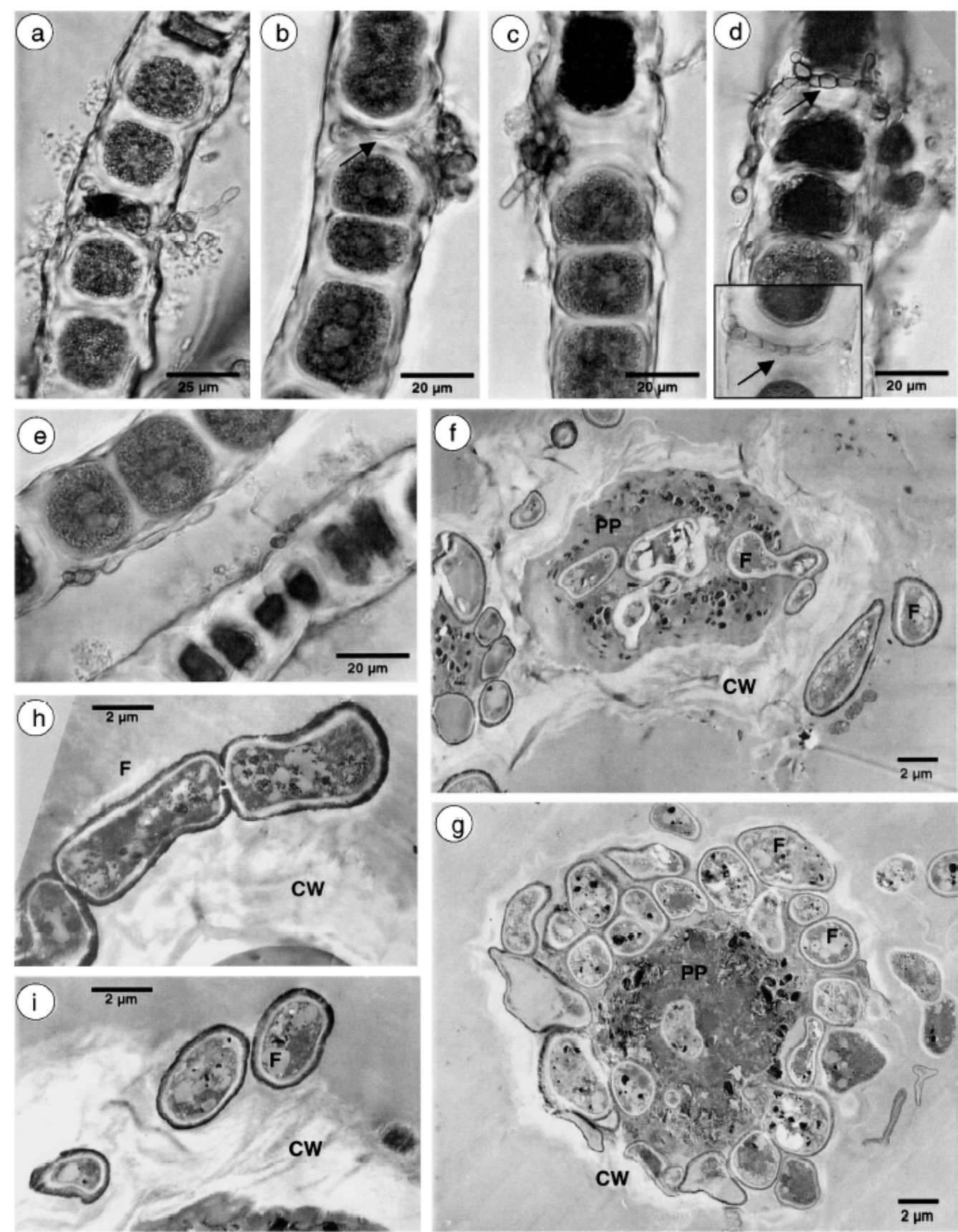

FIGURE 2. Interaction between Zygogonium and Fusarium.

a-e) Infected filaments visualized by light microscopy. Sample from an native soil crust (a, gelatin-embedded), samples taken from liquid cultures after re-infection (b-e). Fusarium hyphae adhere the filament and invade preferentially in intracellular spaces (arrows) before attacking the cell. Infected cells appear dark after infiltration with Ruthenium Red stain. The inset in d) shows an unstained filament. In e), an intact (upper left) and a heavily heavily infected filament (lower right) are depicted.

$\mathrm{f}, \mathrm{g}$ ) Ultrathin sections of infected Zygogonium cells. Sections of fungal hyphae (F) are visible at the surface of and inside the multi-layered Zygogonium cell wall (CW) as well as in the cytoplasm of the protoplast (PP). Especially in (g), a network of filaments (in cross section) surrounds the protoplast, after penetration and disintegration of the wall. In the cytoplasm of the degenerating protoplast, numerous dark granules are noticeable.

h, i) Fusarium hyphae attached to (h) or penetrating (i) the Zygogonium wall (CW). 


\section{Structure of the algal crust}

In spite of the homogeneous surface, the crust composition gradually changes from the top layer to the bottom. The upper crust layer of 1-1.5 mm in thickness is nearly exclusively composed of Zygogonium ericetorum filaments. In this layer, the alga forms a closed mat (Fig. 1c). In an intermediate layer of 1$2 \mathrm{~mm}$, besides the dominating Zygogonium, individual Ulothrix sp. filaments could be detected sporadically, and microcolonies of Gloeocystis sp. are interspersed in the mat (Fig. 1d, g, h). Here, also microcolonies of heterotrophic bacteria in close association with the thick algal capsule are observable (Fig. 1i, j). No cyanobacteria could be detected. In this layer, an ascomycete fungus, Fusarium oxysporum acts as a pathogen to Zygogonium cells. Fig. 2 depicts the mode of attack: the fungal hypha attaches to and penetrates the algal cell wall (Fig. 2a-d, h, i); no haustorial or other special adaptations of the fungal hyphae could be detected. Fungal cells are then in the cellular lumen and finally invade the protoplast of the damaged cell (Fig. 2f, g). In a 2-4 mm thick lowest layer, the Fusarium filaments form a tight web with the sand grains (Fig. 1e). The isolated Fusarium strain could be used to re-infect liquid Zygogonium cultures (Fig 2b-e).

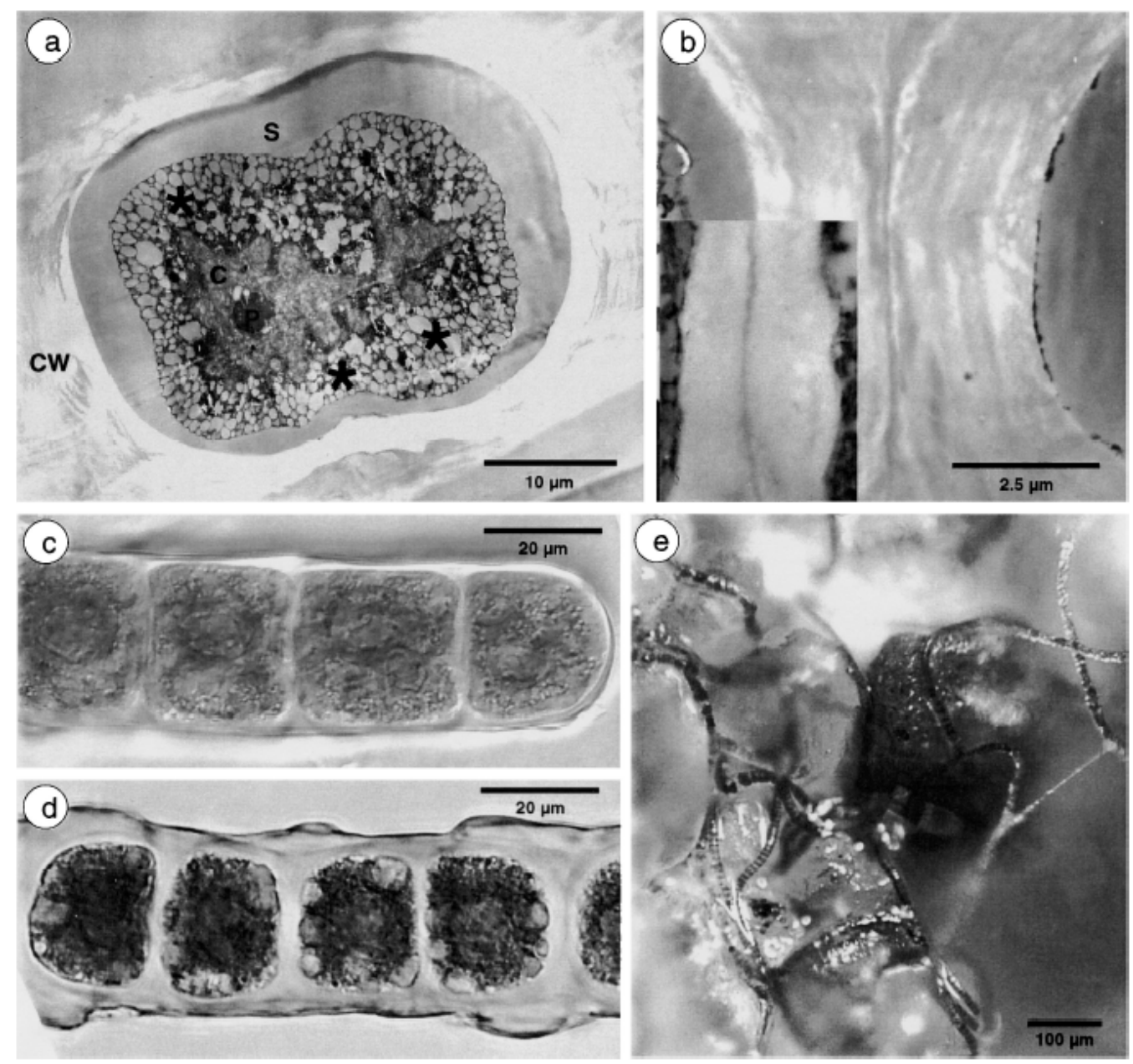

FIGURE 3. Structural features of Zygogonium cells taken from native crusts and liquid cultures.

a) Ultrathin section of a Zygogonium cell taken from a native crust. The cell wall appears bight and multi-layered (compare b), the protoplast is plasmolyzed, leaving a free space (S) between the inner wall layer and the cytoplasmic membrane and the cytosol contains numerous bright granules (asterisks). The lobed chloroplasts (C) are saggitally sectioned; a pyrenoid $(\mathrm{P})$ is visible.

b) Layered cell wall of adjacent cells in a filament taken from the native crust. The thinner, non-layered wall of cells taken from liquid culture is shown for comparison.

c, d) Comparison of Zygogonium ericetorum taken from a liquid culture (c) and from a native crust (d). Besides the thicker wall, the cell taken from the native crust exhibit higher density of small granules and large stroma starch granules (visible at the periphery). The protoplast appears considerably darker due to the purple Zygogonium pigmentation.

e) Zygogonium filaments grown on a sterilized sand bed after 6 weeks of incubation. The filaments built up a loose three-dimensional network surrounding the grains. 
After cultivation axenically (i.e. without detectable contaminations of other organisms), algal filaments were re-transferred to sterile soil surface. During a period of three months at room temperature and under light/dark illumination regime, the algae form a loose mat as depicted in Fig. 3e. Zygogonium cells taken from a native crust exhibit considerably thicker cells walls than cells taken from a liquid enrichment or pure culture, or even the cells grown on a sterile soil surface (Fig. 3b, c, d). In native crusts, the cells are often pigmented (Alston, 1958) and storage granules are visible in the cytoplasm of the cells, which are less abundant in cultured cells (Fig. 3a, c, d).

The micrographs in Fig. $1 \mathrm{~h}$ and $\mathrm{j}$ are indicative for the presence of extracellular polymeric substances (EPS) in the crust system. However, contrary to cyanobacterial soil crust or microbial biofilms, the amount of extractable crust components is low. This feature is supported by the fact that, in spite of the thick, multi-layered wall of Zygogonium, electron as well as light microscopy did not reveal the presence of an polysaccaride capsule or mucilaginous sheath. A standard procedure for the extraction of EPS yielded $125 \mathrm{mg} / \mathrm{kg}$ crust (dry weight). The hydrolyzed polysaccaride mainly consists of glucose and fructose in a 1.2/1 molar ratio.

\section{Photosynthetic activity and desiccation resistance}

The dry algal crust does not show any photosynthetic activity or respiration. Upon moistening, respiration (measured in the dark) starts immediately. At apprx. $50 \%$ of the maximum water holding capacity, respiration rate reaches saturation (Fig. 4). Light saturation, expressed as oxygen production rate is achieved at a light intensity of $35000 \mathrm{~lx}$. Since no photoinhibition (neither in the native crust


FIGURE 4. Respiratory and photosynthetic activities of soil crusts and isolated algae.

a) Initial $\mathrm{CO}_{2}$-production in the dark immediately after rewetting at different water holding capacities.

b) Time course of light-dependent oxygen production rates after rewetting under light saturation. The maximum rate is reached $8 \mathrm{~h}$ after rewetting.

c) Oxygen production rates of crust samples (closed symbols) and Zygogonium taken from liquid culture (open symbols) in glycerol solution (solid lines) and sodium chloride solutions (dashed lines) at different water activities $\left(\mathrm{a}_{\mathrm{w}}\right)$.

d) Photosynthetic activity curves of various algae in glycerol solutions at different $\mathrm{a}_{\mathrm{w}}$. Maximum activities $(100 \%)$, measured in absence of glycerol were $4.5 \mu \mathrm{mol}$ oxygen/(g chlorophyll $\mathrm{x}$ min) for Macrochloris multinucleata, $1.3 \mu \mathrm{mol}$ oxygen/(g chlorophyll $\mathrm{x} \mathrm{min}$ ) for Arthronema africanum and $1.6 \mu \mathrm{mol}$ oxygen/(g chlorophyll x min) for Klebsormidium flaccidum. 
nor in enrichment of pure cultures) has been observed, photosynthetic activities were routinely measured at $50000 \mathrm{~lx}$. Though respiration starts immediately upon moistening, photosynthetic oxygen production continuously increases over a period of 8 hours under illumination at light saturation (Fig. 4b). Thus, $\mathrm{CO}_{2}$ uptake equilibrates $\mathrm{CO}_{2}$ production at $3 \mathrm{~h}$ after moistening under light saturation. At lower light intensities, the equilibrium is reached later (e.g. after $5 \mathrm{~h}$ at $25000 \mathrm{~lx}$ ). For determination of photosynthetic activity in liquid media, it must be considered that the crust organisms are adapted to an acidic soil. However, though Zygogonium in pure liquid culture has a maximum growth rate between $\mathrm{pH} 3.5$ and 5, maximum photosynthetic activity is constant between between $\mathrm{pH} 4$ and 8 . Algal crust samples exhibit a constant maximum photosynthetic activity between $\mathrm{pH} 4$ and 7 . The broad $\mathrm{pH}$ dependence allows conducting measurements of the photosynthetic activity at various water activities under neutral $\mathrm{pH}$ in glycerol as well as sodium chloride solutions. Measurements were conducted with crust samples showing maximum photosynthetic activity after moistening and pre-incubation for $8 \mathrm{~h}$. The organisms taken from liquid cultures, of course, did not need any pre-incubation. At highest water activity, all samples developed nearly exactly the same photosynthetic activity, expressed as oxygen production $(0.8 \mu \mathrm{mol}$ oxygen/[g chlorophyll $\mathrm{x} \mathrm{min}])$. At lower water activities, however, the Zygogonium cells taken from a liquid culture exhibited considerably lower photosynthetic activity than the native algal crust (Fig 4c). This is - in principle - true for glycerol as well as sodium chloride containing solutions. In glycerol, the overall photosynthetic activity appears to be higher as in sodium chloride solutions (Fig. 4c). The activity of Zygogonium has been compared with the photosynthetic oxygen production rates of other algae under reduced water activity (Fig. 4d). The isolated Zygogonium cells exhibited a similar course of activity as the cyanobacterium Arthronema africanum or the green alga Macrochloris multinucleata. Both organisms have been described for crusts from desert soil. Klebsormidium flaccidum cells, which are present in soil as well as freshwater habitats, did show considerably higher sensitivity against a low water potential.

\section{Discussion}

\section{Occurrence of Zygogonium-dominated crusts}

The biological crusts in the "Glauer Berge" area located on hill tops of a terminal moraine in an open sand grassland (Spergulo-Corynephoretum) and an open acid sandy soil pinewood (Cladonio-Pinetum corynephoretosum). Historical land survey maps show that the forest was established predominantly by natural succession on former grassland during the 19th century and the first half of the 20th century (Heinken 1999). Thus, it may be estimated that the study site is more or less undisturbed for at least 50 years and Zygogonium resists succession by phanerogams as well as higher cryptogams for decades. Zygogonium ericetorum has been listed in a number of species records as species of dry crusts in grassland or on inland dunes (Van der Drift 1964, Pluis 1994, Paus 1997, Büdel 2001) but also for wetland stands, especially as pioneer alga or in successional stages (e.g. Karofeld 1998, Pope and Pyatt 1984, Neuhaus 1990) where filaments form thick and permanently hydrated mats instead of crusts. However, when succession comes to an arrest due to the unfavorable edaphic and microclimatic conditions, the algae build up a thick and permanent crust cover. This feature may be promoted by the Zygogonium crust itself, as described by Pluis (1994) for inland dunes of the Laarder Wasmeer: once established, the crust cover reduces water infiltration and increases surface runoff at sloping sites, which may further inhibit succession.

\section{Interaction between Zygogonium and Fusarium}

Up to now no detailed information concerning microstructure and composition of Zygogonium-dominated soil crusts is available. Concerning the dominance of the two species Zygogonium (in the upper layer) and Fusarium (in lower layers) these two organisms appear to be the most essential for crust formation. Though syntrophic associations are known as significant features of microbiotic crusts (e.g. States et al. 2001), and the occurrence of the fungal pathogen Chloridium in association with Zygogonium ericetorum has been mentioned (Pope and Pyatt, 1984), the pathogenic interaction between Fusarium and Zygogonium has not yet been described so far. Though certain fungal species are parasites on marine microalgae (see e.g. Schnepf 1994, Gromov et al. 2000), it appears reasonable to assume that parasitic interactions are also widespread between fungi and algae from other habitats (Hutchison and Barron, 1997). Parasitic interactions between ascomycete fungi including Fusarium and higher plants are widespread, and a number of variable infection modes are well documented (e.g. Perfect and Green, 2001). Though no specialized infection structures could be observed in our study, it 
is obvious that Fusarium hyphae first enter the intercellular space between adjacent cells of a living Zygogonium filament and then actively penetrate the thick multi-layered wall of a single cell, grow intracellularly and induce obvious morphological alterations in the cytoplasm of the algal cell, until the whole protoplast is decomposed (Fig. 2). As depicted in Fig 2 a-d, often the H-shaped wall segment, which is also a pre-determined breaking point for thallus fragmentation is penetrated, before a hypha enters the cell via a transversal wall. By this way, adjacent cells of a filament are frequently infected at the same time. Though the Fusarium infection is deleterious to a single cell or smaller segments of a filament, it could never be observed that the fungus overgrows the Zygogonium filaments. In the lower, Fusarium-dominated layer of the crust, however, a majority of the algal filaments is infected. It is, of course, reasonable to assume that Zygogonium and the fungus establish a stable equilibrium of growth rates and decomposition rates.

\section{Response to Desiccation}

Measurement of photosynthetic activity in solutions at defined water potentials is selected in this study as a most straightforward approach for quantification of desiccation resistance. For a better validation of the assay, an ionic as well as a non-ionic compound (sodium chloride and glycerol) were used. Native algal crust samples, in fact, exhibited higher resistance to low water activities as Zygogonium cells grown axenically in liquid culture (Fig. 4c). The results are true for sodium chloride as well as glycerol containing solutions; both assay curves show the same trend with different absolute values. The adaptation to low water potential of native crust samples (and still of the isolated Zygogonium) corresponds to the results that could be obtained with an other eukaryotic microalga (Macrochloris multinucleata) and a cyanobacterium (Arthronema africanum). Both algae have been described as crust organisms in desert soils (Komarek and Lukavsky 1988; Lange et al., 1992). The alga Klebsormidium flaccidum appeared to be less adapted to low water potentials. This alga has also been described for terrestrial habitats, but has wide ecological amplitude and was also frequently isolated from freshwater habitats.

The underlying mechanism for the adaptation of Zygogonium to low water potential has yet to be elucidated. The Zygogonium crust did only contain a low amount of extractable polymers, mainly consisting of glucose and fructose in approximately equimolar ratios. These compounds may be rather product of the bacteria detected in the crust, but do not account for a polysaccaride produced by a eukaryotic alga (Steinbüchel et al., 2002). Thus, it is unlikely that extracellular polymers play an important role in protection against desiccation of the alga. The Zygogonium cell wall itself may influence the resistance of the cells against desiccation stress. The wall appears in crust samples by three to five times thicker than in cells grown in liquid culture (Fig 3a, b). Thick, multi-layered walls may reduce rapid evaporation of water upon drying and protect the algal protoplast from burst when the turgor rapidly increases upon rewetting (Bisson and Kirst, 1995). The effect of osmoprotective compatible solutes during desiccation should be noticeable after some minutes to one hour of incubation in a medium with reduced water activity (Kirst 1989 and references therein). In our study, even overnight pre-incubation of liquid culture samples did not significantly change the differences in oxygen evolving activity, which does not account for induction of compatible solute synthesis. Thus, other protective mechanisms must exist and may be more active in cells from the native crusts than in cells taken from a culture liquid. It is obvious that Zygogonium cells, especially when taken from the native crust, contain a huge number of cytoplasmic vesicles and granules; the cytoplasm of Zygogonium cells appears like a lipid emulsion (Fig 3a). Accumulation of cytoplasmic lipid granules (as well as an increase in cell wall thickness) has also been described as a response to desiccation stress for Klebsormidium rivulare (Morison and Sheath, 1985). The storage granules, as a side effect of their composition of non-polar compounds and an amphiphilic membrane surface, may stabilize the cellular proteins in their immediate surrounding. This effect has frequently been described for emulsions of enzymes (with a residual degree of hydration) in non-polar media in vitro. Emulsification of proteins in these media as well as immobilization or microencapsulation on hydrophobic polymers enhances their temperature resistance; this feature has also been applied in a number of biotechnological processes (see e.g. Gupta 1992; Hoppert and Mayer 1999 and references therein; Klibanov 2001).

\section{Acknowledgements}

We are indebted to W. Manz (TU Berlin) and G. Arp (Univ. Göttingen) for providing in situ hybridization probes and access to an image deconvolution system. We thank C. Grüber for excellent technical assistance at the scanning electron microscope. 


\section{References}

Alston RE. (1958). An investigation of the purple vacuolar pigment of Zygogonium ericetorum and the status of algal anthocyanins and phycoporphyrins. Am J Bot 45:688-692.

Belnap J, Kaltenecker JH, Rosentreter R, Williams J, Leonard S Eldridge, D. (2001). Biological soil crusts: ecology and management, Denver: US Dept. of the Interior/Bureau of Land Management.

Berger-Landefeldt U. (1964). Über den Strahlungshaushalt verschiedener Pflanzenbestände. Ber Dtsch Bot Ges 77:27-48.

Bisson MA, Kirst GO. (1995). Osmotic acclimation and turgor pressure regulation in algae. Naturwissenschaften 82:461-471.

Büdel B. (2001). Biological soil custs of South America. In: Belnap J, Lange OL, eds. Biologicals Soil Crusts: Structure, Function and Management (Ecological Studies, vol 150), Heidelberg: Springer p 51-55.

Delieu T, Walker DA. (1972). Improved cathode for measurement of photosynthetic oxygen evolution by isolated chloroplasts. New Phytol 71:201-225.

DSMZ (2001). Catalogue of Strains, Deutsche Sammlung von Mikroorganismen und Zellkulturen: Braunschweig.

Eldridge DJ, Rosentreter R. (1999). Morphological groups: A framework for monitoring microphytic crusts in arid landscapes. J Arid Environ 41:11-25.

Gromov BV, Mamkaeva KA, Pljusch AV. (2000). Mesochytrium penetrans gen. et sp. nov. (Chytridiales) - a parasite of the green alga Chlorococcum minutum (Chlorococcales), with an unusual behaviour of the sporangia. Nova Hedwigia 71:151-160.

Gross M, Rudolph K. (1987). Studies on the extracellular polysaccharides (EPS) produced in vitro by Pseudomonas phaseolicola.1. Indications for a polysaccharide resembling alginic acid in 7 Peudomonas syringae pathovars. J Phytopathol 118:276-287.

Gupta, MN. (1992). Enzyme function in organic solvents. Eur J Biochem 203:25-32.

Heinken T. (1999). Die Kiefernwälder der Glauer Berge - ein Beispiel für die Rolle der Kiefer in der Waldsukzession auf Sandböden in Mittelbrandenburg. Gleditschia 27:79-96.

Hoppert M, Holzenburg, A. (1998). Electron Microscopy in Microbiology, RMS Handbook Series, Oxford: Bios Scientific Publ.

Hoppert M, Mayer F. (1999). Principles of macromolecular organization and cell function in bacteria and archaea. Cell Biochem Biophys 31:247-284.

Hoppert M. (2003). Microscopic Techniques in Biotechnology, Weinheim: Wiley-VCH.

Hutchison LJ, Barron GL. (1997). Parasitism of algae by lignicolous Basidiomycota and other fungi. Can J Bot 75:1006-1011.

Johansen JR. (1993). Cryptogamic crusts of semiarid and arid lands of North America. J Phycol 29:140-147.

Karofeld E. (1998). Effects of bombing and regeneration of plant cover in Konnu-Suursoo raised bog, North Estonia. Wetland Ecol Management 6:253-260.

Kirst GO. (1989). Salinity tolerance of eukaryotic marine algae. Annu Rev Plant Physiol Plant Mol Biol 40:2153.

Klibanov AM. (2001). Improving enzymes by using them in organic solvents. Nature 409:241-246.

Komarek J, Lukavsky J. (1988). Arthronema gen. nov. - a new cyanophyte genus from Afro-Asian deserts. Arch Hydrobiol. Suppl. 80:249-268.

Lange OL, Kidron GJ, Büdel B, Meyer A, Kilian E, Abeliovich A (1992). Taxonomic composition and photosynthetic characteristics of the "biological soil crusts" covering sand dunes in the western Negev Desert. Funct Ecol 6:519-527.

Labuza TP. (1975). Interpretation of sorption data in relation to the state of constituent water. In: Duckworth R, ed. Water Relations of Foods, New York: Academic Press p 155-172.

Lukesova A. (2001). Soil algae in brown coal and lignite post-mining areas in central Europe (Czech Republic and Germany). Restoration Ecol. 9:341-350.

Manz W, Amann LW, Wagner M, Schleifer K-H. (1992). Phylogenetic oligodeoxynucleotide probes for the major subclasses of Proteobacteria: problems and solutions. System Appl Microbiol 15:593 - 600.

Manz W, Arp G, Shumann-Kindel G, Szewzyk U, Reitner J. (2000). Widefield deconvolution epifluorescence microscopy combined with fluorescent in situ hybridisation to show the spatial arrangement of bacteria in sponge tissue. J Microbiol Meth 40:125-134.

Morison MO, Sheath RG. (1985). Responses to desiccation stress by Klebsormidium rivulare comb. nov. (Ulotrichales, Chlorophyta) from a Rhode Island stream. Phycologia 24:129-145

Nehring K. (1960). Agrikulturchemische Untersuchungen für Dünge- und Futtermittel, Böden und Milch, Hamburg: Parey.

Neuhaus R. (1990). Stages and ages of primary heath succession in coastal dunes. Drosera 90:29-34.

Paus SM. (1997). Die Erdflechtenvegetation Nordwestdeutschlands und einiger Randgebiete (Bibl. Lichenol. 66), Stuttgart: Borntraeger.

Perfect SR, Green JR. (2001). Infection structures of biotrophic and hemibiotrophic fungal plant pathogens. Mol Plant Pathol 2:101-108. 
Pluis JLA. (1994). Algal crust formation in the inland dune area, Laarder Wasmeer, the Netherlands. Vegetatio 113:41-51.

Pope CR, Pyatt, FB. (1984). Aspects of the ecology of Zygogonium ericetorum (Kütz) on china-clay tips. Int. J. Environ. Studies 23:217-227.

Potts M. (1999). Mechanisms of desiccation tolerance in cyanobacteria. Eur J Phycol 34: 319-328.

Prasse R, Bornkamm R. (2000). Effect of microbiotic soil surface crusts on emergence of vascular plants. Plant Ecol. 150:65-75.

Schlösser UG. (1994). SAG - Sammlung von Algenkulturen der Universität Göttingen. Catalogue of strains 1994. Bot Acta 107:113-186.

Schnepf E. (1994). A Phagomyxa-like endoparasite of the centric marine diatom Bellerochea malleus - a phagotrophic plasmodiophoromycete. Bot Acta 107:374-382.

Spurr AR. (1969). A low viscosity epoxy resin embedding medium for electron microscopy. J Ultrastruct Res 26:31-43.

Starr RC. (1971). Algal cultures - sources and methods of cultivation. Meth Enzymol 23:29-53.

States JS, Cristensen M, Kinter CL. (2001). Soil fungi as components of biological soil crusts. In: Belnap J, Lange OL, eds. Biological Soil Crusts: Structure, Function and Management (Ecological Studies, vol 150), Heidelberg: Springer p 155-166.

Steinbüchel A, De Baets S, Vandamme EJ. (2002). Biopolymers vol 6; Polysaccharides II: Polysaccharides from Eukaryotes. Wiley-VCH, Weinheim.

Van der Drift J. (1964). Soil fauna and soil profile in some inland dune habitats. In: Jongerius A, ed. Soil Micromorphology. Elsevier: Amsterdam p 69-81.

Venable JH, Coggeshall R. (1965). A simplified lead citrate stain for use in electron microscopy. J Cell Biol 25:407-408.

Verrecchia E, Yair A, Kidron GJ, Verrecchia K. (1995). Physical properties of the psammophile cryptogamic crust and their consequences to the water regime of sandy soils, north-western Negev Desert, Israel. J Arid Environ 29:427-437 